Article

\title{
Towards Strategic Business Performance of the Hospitality Sector: Nexus of ICT, E-Marketing and Organizational Readiness
}

\author{
Muhammad Khalid Anser ${ }^{1}$, Zahid Yousaf ${ }^{2, *(D)}$, Muhammad Usman ${ }^{3}{ }^{-0}$ and Seemab Yousaf ${ }^{2}$ \\ 1 Xi'an University of Architecture and Technology, Xi'an 710055, China; mkhalidrao@xauat.edu.cn \\ 2 Government College of Management Sciences, Abbottabad 22010, Pakistan; seemab.yousafkpk@gmail.com \\ 3 COMSATS University Islamabad, Lahore Campus 1.5 KM Defense Road, off Raiwind Road, Lahore 54000, \\ Pakistan; hmusman@cuilahore.edu.pk \\ * Correspondence: muhammadzahid.yusuf@gmail.com
}

Received: 12 January 2020; Accepted: 7 February 2020; Published: 12 February 2020

\begin{abstract}
Purpose: This study aims to present a strategic business performance (SBP) model for firms operating in the hospitality industry by providing them guidance on how to use information and communication technologies (ICTs) and e-marketing to attain strategic performance. This paper also explores the moderating role of organizational readiness in the relationship between ICT and e-marketing. Methodology: Data were collected from the top, middle, and operational managers in 4-star and 5-star hotels. To test the mediating role of e-marketing in the relationship between ICT and SBP, Preacher and Hayes's (2008) approach was used along with the bootstrap method. Regression analysis was carried out to examine the moderating role of organizational readiness. Findings: ICTs provide opportunities to execute e-marketing activities for achieving competitiveness. The empirical findings proved that the use of ICTs provides a basis for establishing a successful e-marketing mechanism that helps hotels to achieve SBP. Furthermore, ICTs' influence on e-marketing is strengthened by organizational readiness. Originality/value: This paper adds to previous literature on ICTs, SBP, and e-marketing by examining the role of e-marketing and ICTs in positively contributing to the hotels' SBP, which is a broader measure of firms' business performance, as compared to the traditional financial or operational measures of a firm's performance. Since previous studies on the links between ICTs, e-marketing, and firm performance are based on conventional measures of firm performance, this study offers new insights into the nexus of ICTs, e-marketing, and firm performance.
\end{abstract}

Keywords: strategic business performance; information and communication technology; e-marketing; organizational readiness; hospitality; Pakistan

\section{Introduction}

The growing trend in the use of information technology and web-based activities has received substantial attention from researchers to investigate their impact on business and commerce [1,2]. The use of information and communication technologies (ICTs) in business practices, processes, product development, strategy, and decision making has significantly contributed to change in businesses' patterns and economic growth of various industry sectors [3,4], including the hospitality and tourism industry [5,6]. Past research has been impressive in examining and bringing to the fore the role of ICTs on employee and organization productivity and performance $[1,7,8]$. Indeed, ICT has been reported to have positive influences on organizational development [2,9], innovation [10], operational performance [11], competitiveness [12], employment [8], sales force activities [13], and the enterprise information system [14]. Likewise, ICT adoption offers a broad range of opportunities for developing 
the hospitality sector [15]. ICT adoption improves productivity [16], increases output level, and boosts multi-factor productivity [12,16], and thus, results in superior performance and sustainability [9]. Recent reviews [1,5] also show that ICTs play an important role in hospitality firms' productivity and performance.

Despite making impressive contributions, critical omissions in the literature on the links between the use of ICT and firm performance need to be filled to advance this research stream. First, past research on the links between ICT and firm performance has mainly focused on the financial and operational indicators of firms' business performance. Although insightful, the focus of prior work on the ICT-firm performance linkage in the hospitality and tourism industry has been on the traditional financial and operational indicators of firms' business performance [6,17]. The use of financial or operational measures of performance, however, does not offer a holistic view of the firms' strategic business performance $[6,17,18]$. Focusing on conventional business performance measures not only provides incomplete information about firms' business performance but also limits owners' and managers' capability to think strategically and develop strategic interventions, to gain a sustainable competitive advantage [6,17].

The concept of SBP has emerged as one of the leading research areas in management research in the last decade, as it offers a more complete understanding of a firm's business performance $[6,18]$. SBP brings sustainability through the achievement of financial and competitive targets, i.e., sustaining business performance for longer time-periods. SBP helps firms to achieve their marketing objectives by positively contributing to the firms' sales, market share, and profitability. SBP helps to accomplish firms' long-term goals by facilitating consistent improvement, as well as innovation in practices, processes, products, and services [18]. However, extant literature, including the hospitality literature has ignored the effect of ICT on SBP. These are surprising omissions, given the ever-growing research on ICT and SBP. SBP is a more comprehensive measure of a firm's business performance and helps organizations devise appropriate strategic interventions for achieving long-term goals and sustainable competitive advantage.

Second, due to the lack of research on the ICT-SBP links, our knowledge of the underlying mechanisms of this ICT-SBP association is meager at best. Prior general literature, as well as existing hospitality literature, has glossed over the interrelations between ICT, e-marketing, and SBP. To address this gap, we suggest that e-marketing, which is one of the most prominent outcomes of ICT [12], mediates the relationship between ICT and SBP. E-marketing through emails, social networking websites, mobile, and other such platforms play an imperative role in grabbing customer attention, facilitating the sale/purchase process, and information sharing $[1,12,19]$ that, in turn, can help firms to achieve SBP. Moreover, we argue that the relationship between ICT and e-marketing is complex rather than straightforward. To foreground the complexities involved in this relationship between ICT and e-marketing, the present research also analyzed the moderating impact of organizational readiness in the interplay between ICT and e-marketing. Organizational readiness refers to a firm's capability to effectively adopt and implement a change to counter the changing market trends [20]. Managerial expertise along with trained staff, flexibility in strategy, operations, and adequate financial resources are important manifestations of organizational readiness to adopt change $[17,20]$.

Finally, past research has predominantly focused on the effect of ICT and e-marketing on various facets, such as innovation, and financial and operational performance of the hospitality sector firms of the developed countries [21]. However, despite the obvious significance of the hospitality sector in economic stabilization and the growth of developing countries [22], relatively less is known about the role of ICT and e-marketing in improving the SBP of the hospitality sector in the context of developing countries. To fill in this research gap, we contextualized our theoretical framework in a developing country, Pakistan. Our interest to contextualize the theoretical links between ICT, e-marketing, and SBP in Pakistan was inspired mainly by the growing attention the country has received as a popular tourist place, in the past couple of decades [6]. Pakistan is best known for its soaring mountains, such as K2, the largest glacier in the world, Batura, and several beautiful destinations that have received massive 
attention from international tourists, which have significantly boosted the tourism and hospitality industry in the country [6]. Figure 1 depicts our research model.

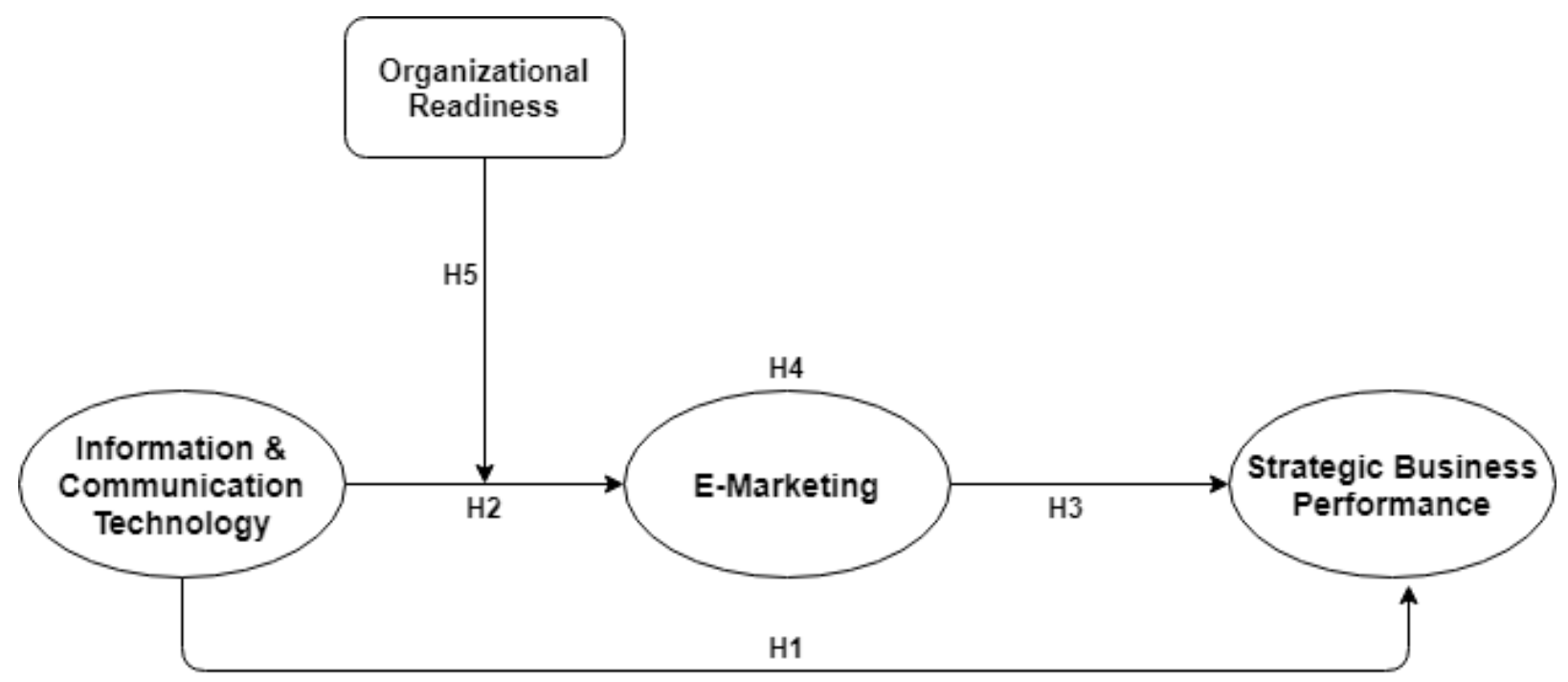

Figure 1. A strategic business performance model for the hospitality industry.

In sum, this paper develops a strategic business performance model (SBPM) for the hospitality sector that examines and explains the role of ICT and e-marketing in positively affecting the SBP. In doing so, the present work contributes to the ICT literature by empirically showing the consequential potential of ICTs for shaping hospitality firms' e-marketing practices, as well as SBP. Moreover, the SBPM framework shows that e-marketing mediates the ICT-SBP link, explicating why ICTs positively affect SBP. In this way, the present study contributes to the literature on e-marketing by enhancing the firms' networks and consequences of e-marketing in the hospitality sector. The SBPM framework also contributes to the literature on the links between ICT and e-marketing, as well as the literature on organizational readiness by establishing that organizational readiness strengthens the relationship between ICT and e-marketing in the hospitality industry. This research can be helpful in the hospitality industry for management departments that aim to achieve superior performance and gain a sustainable competitive advantage. This study can lead the hospitality firms' management to take initiatives to transform their traditional business activities by focusing on the effective use of ICT in organizational practices.

This paper is arranged as follows. Hypotheses regarding the interrelations between ICT, e-marketing, organizational readiness, and strategic business performance are presented in Section 2. The methodology is presented in Section 3, and the analysis is provided in Section 4. The final Section 5 is composed of discussion, theoretical contributions, practical implications, limitations, and future research directions.

\section{Hypotheses Development}

\subsection{ICTs and Strategic Business Performance}

ICT refers to the collection of information, communication management tools and techniques, software, hardware, peripheral devices, and their effective application to impart, decode, store, and alter information [9]. Previous work concluded that sustainable development and the use of ICTs have a great tendency to improve firms' productivity [23] and growth potentials [24]. This study proposes that ICT positively affects the hospitality firms' SPB. SBP is a broader concept that entails different critical areas, such as improvement firms' competitive position, marketing, and sales, organizational development and transformation, and firms' operational and financial performance. SBP is also 
considered to be a business approach that helps firms accomplish their marketing strategies and attain their strategic goals $[6,17]$.

ICTs have become an essential component of organizations in today's dynamic and competitive business environment [25]. Businesses that efficiently use ICTs in their operations can gain a strong foothold in the market and achieve sustainable competitive advantage [26]. Firms' inclination toward the adoption of ICTs in organizational practices and processes has increased because it brings positive financial returns [27]. Moreover, the use of ICTs has removed several physical communication channels, facilitated fast and more effective communication with customers through e-mail, social media, and mobiles, and reduced the communication cost [25]. The present business environment is highly competitive and dynamic. Using ICTs in business strategy and operations have offered firms numerous opportunities to stay competitive by developing and exploiting strong relationships with customers, suppliers, and dealers, reducing the operational cost and achieving greater market value [28,29].

The benefits of integrating ICTs in the managerial activities of organizations, such as strategy formulation, complex decision-making, knowledge management, and top-down information flow, can help an organization perform strategically [30]. Inventory management software, decision-making software, accounting software, product-designing software, and information management software are examples of ICTs' assistance, through which organizations save both time and cost [4]. Enhancing employees' access to necessary information, and developing harmonious relationships among them and with the top management through ICT tools, positively influence firm performance [31]. ICT has opened up new business opportunities for organizations by providing rapid and convenient access to market information [32]. Geographical boundaries remain no longer a barrier due to the development of ICTs, which has resulted in enhanced market size and more profit potentials [33]. ICTs not only enhance firms' productivity, profitability, and growth but also bring improvement in the provision of better customer services [34]. ICT is a key driver of innovation in practices, products, and service delivery that help the firms compete in a strategic manner [33]. Therefore, it is argued that the use of ICTs positively affects the hospitality firms' SBP.

H1: Use of ICTs is positively associated with strategic business performance.

\subsection{ICTs and E-Marketing}

E-marketing refers to the utilization of electronic media to accomplish marketing goals and objectives [35]. Different ICT-enabled tools and techniques have continued to support and augment marketing activities since the mid-twentieth century [36]. E-marketing, i.e., ICT-enabled marketing activities, such as information sharing, customer support, customer relationship management, marketing research, and strategic planning result in improved financial and operational performance of firms [30]. ICT is a valuable mechanism, which is based on a set of software, peripheral devices, hardware, and mobile technologies that provide firms with several opportunities to execute e-marketing activities [14,29]. The switch in marketing practices from traditional ways is an outcome of technology implementation. The deployment of ICTs leads to more effective marketing practices [14]. The positive impact of ICTs on marketing can be witnessed in local and global markets [36]. Barwise and Farley [3] in their surveys on marketing, conducted in several countries (Japan, Germany, Brazil, United States, United Kingdom, and China), concluded that the rapid growth of technology, its utilization in advertisement, and the exchange of messages between the customer and the marketer, have removed geographical boundaries and other such communication barriers between an organization and its customers. ICTs have enabled marketing executives to increase their firms' influence on target markets and the level of penetration in new markets [30]. Consistent information sharing with customers without time and space constraints are imperative aspects of e-marketing.

With the help of mobile communication, marketing professionals can develop a direct link with customers, win their trust, and make them loyal $[35,36]$. Due to the increasing use of ICTs by customers, information sharing through mobiles, web-based technologies, and social media has emerged as an 
important source of gaining and maintaining customer loyalty and trust [37]. ICTs have broadened the access of marketers to a wide range of customers that are scattered in diverse geographically areas [3]. As a result of the evolution of information technology, businesses have invested numerous resources to exploit the internet for the expansion of their products and services to new markets [28,29]. ICTs play an imperative role in amplifying marketing efforts and helping business firms achieve their marketing goals and objectives [27].

H2: The use of ICTs is positively associated with e-marketing.

\subsection{E-Marketing and SBP}

Carrying out marketing functions through electronic media has reduced costs related to marketing and operational activities by shifting physical channels to the electronic medium [38]. Through electronic devices and other electronic media, particularly social media, organizations establish direct and more personalized relationships with the customers scattered over expanded geographical boundaries [36]. Customers can directly acquire information and produce speedy feedback. Such prompt actions play a supportive role in altering the marketing efforts according to the customers' needs, ultimately helping the firms to achieve sustainable growth [38].

Sales performance is improved through the availability of online shopping facilities in which sales, purchases, and payments are more convenient, as compared to the conventional physical channels [39]. Augmented sale activity level has eventually increased the revenues, as well as the profit margin [36]. Developing long-term relationships with the customer and making them loyal are among the most important targets of today's market that help firms minimize customer brand switching and reduce promotional costs [40]. Through electronic marketing channels, businesses can achieve their goals more efficiently and effectively [38]. Direct association with customers through interactive technologies create online brand communities that help businesses attract and retain customers and improve their strategic performance [41].

Electronic word-of-mouth is a prominent marketing activity for generating revenues and grasping more effective results, as compared to traditional marketing practices [42]. Online promotions and advertisements have amplified the exposure of a firm and its offerings to customers [39]. Such improved e-marketing efforts enhance market growth, which leads to maximized revenues and profit [41]. Therefore, the integration of ICTs in marketing activities has provided opportunities for establishing long-term relationships, creating customer loyalty, and gaining access to a wider customer base, which can not only result in the improved operational and financial performance of firms but can also enhance firms' foothold in the market. Thus, the following hypothesis was developed.

H3: There is a positive relationship between E-marketing and SBP.

\subsection{Mediation by E-Marketing}

Many researchers have researched and found a positive impact of the use of ICTs on marketing activities $[30,43,44]$. Such ICT-based marketing initiatives set the foundations for long-term business success in the form of sustainable competitive advantage [40]. Therefore, it is argued that e-marketing can be tested as a mediating variable in the ICT-SBP relationship. In today's highly advanced business environment, every business is trying to perform and, therefore, they are focusing on their electronically supported marketing functions [30,38]. Marketers are using ICTs to support their organizational e-marketing so that they can improve business performance in all dimensions $[30,45,46]$. A highly entrenched element of ICT in customer life is the mobile phone, which has allowed businesses to be attached to them on a $24 / 7$ basis $[47,48]$.

E-marketing activities through mobile phones and the use of the internet can develop strong personalized relationships with the customers, which can reduce brand-switching [30,47]. ICT is a key driver to perform marketing practices through electronic media that maximizes financial 
performance [49]. Speedy information sharing through ICT tools helps firms conduct marketing research and planning in a more effective way, which in turn helps firms to improve their SBP [50]. Top and middle-level managers are highly motivated to shift to electronic marketing activities from conventional marketing practices, and such a shift has increased the profit margins and reduced costs [51]. Internet and social media have increased the efficiency and effectiveness of the marketing function that has enhanced online marketing and sales [52]. Boost in sales due to such e-marketing efforts has increased productivity and enabled the hospitality industry to achieve its strategic goals and gain a competitive advantage $[50,53]$. Therefore, it could safely be argued that e-marketing plays the role of a bridge in the ICT-SBP relationship.

The use of ICTs has reduced the limitations related to geographical boundaries and has enabled firms to focus on a wide range of markets, through a number of media [34,42,51]. The increased market size has boosted the overall profitability [36,42]. Mobile and internet technology has provided hotel management with several opportunities to build long-term relationships with their customers by offering them customized offerings $[19,22,25,53]$. The deliverance of service through electronic channels has the potential to improve the hospitality sector's performance [14,21-24,51]. The use of ICTs helps firms to gain a sustainable competitive advantage by upgrading the service delivery to customers, broadening the market size and growth potential, developing strong relationships with customers, promoting loyalty, and providing access to new business opportunities [50,51]. Thus, e-marketing brings sustainability to business performance. Several product-designing software are the important outcomes of ICTs that have enhanced the creativity and innovation in product offerings by marketers, which can result in a competitive advantage [14,53]. Based on the above discussion, the following hypothesis was formulated.

H4: The relationship between the use of ICTs and SBP is mediated by e-marketing.

\subsection{Moderation by Organizational Readiness}

Organizational readiness is the ability to implement, utilize, and gain competitive advantage by adopting and implementing technological improvements [26]. Organizational readiness to change is the main driving force to change traditional practices in a volatile business environment [26]. The significance of ICTs' influence on e-marketing is obvious and has been further improved by the change in conventional marketing practices of businesses of all sizes and types, including firms operating in the hospitality industry [53]. Although the impact of ICTs on strategic performance is obvious, organizational readiness helps firms to speed up their service delivery mechanism by offering convenience to its customers through online channels [30,54,55]. Organizational readiness shows the propensity of any organization to adapt to required changes, and thus, strengthens the relationship between ICT and e-marketing [56,57].

Organizations with a strong readiness capability can utilize its existing resources and make more effective use of new opportunities, to accomplish their e-marketing targets $[15,54,57,58]$. Therefore, it is argued that the relationship between ICT and e-marketing could be strong for firms with high organizational readiness. In a technology-oriented business environment marked by radical change, both readiness for change and the use of ICTs are obligatory for launching successful e-marketing campaigns $[54,59,60]$. Organizational readiness is considered a helpful factor for the hospitality sector to boost e-marketing functions [54,60]. Therefore, it is stated that organizational readiness positively moderates the relationship between ICT and e-marketing. The following hypothesis is suggested based upon the above discussion:

H5: Organizational readiness moderates the positive relationship between ICT and e-marketing, such that the relationship is strong when organizational readiness is high. 


\section{Methodology}

The hospitality industry has been focused on in this study. The hospitality sector operates in a competitive environment, which pushes hospitality firms to perform in a strategic way by implementing ICT and e-marketing systems. Pakistan hotels are at the brink of revolutionary edge and their search to enhance their performance cannot merely depend on their services; they have to also adopt the latest ICTs and e-marketing strategies to stay competitive in the dynamic business environment.

\subsection{Sample Size and Data Collection}

Data were collected from hotels that met the international criteria to be considered as; 5-star and 4 -star hotels. These hotels were carefully screened on the basis of three major assessment criteria. First, the hotels must have enough space, high-class buildings, and other luxurious facilities. Second, hotels must offer high-quality services. Third, the hotels must be preferred to stay by national and international celebrities, international tourists, and other formal/informal foreign delegations.

The data collection team consisted of 15 research assistants ( 5 students of the Master of Business Administration (MBA), 5 students of Master of Science (MS) students, and 5 national internees who had completed their master's degrees in management and commerce). One-month training was provided to these 15 research assistants who spent six months in data collection. Data were collected in 3 phases to avoid common method bias. The data collection team made initial contact with 1100 managers/owners through personal visits, and over $90 \%$ showed consent to participate in the data collection. The questionnaires were distributed along with a cover letter explaining the necessary details about the purpose of research and confidentiality. Furthermore, the research assistants personally visited each hotel and met with each respondent and asked them for a prompt response.

Survey questionnaires are the most widely used tools for measuring self-sufficient existing relationships and self-reported beliefs and behaviors. A survey questionnaire was suitable for this research as it was beneficial in numerous ways; it makes the data collection procedure also, achieves a high response rate, and saves time and costs. Furthermore, data collection team members (15 trained research assistants) ensured that data were collected in a highly cooperative manner and all respondents showed full confidence and responded sincerely, hence the data were real.

In the first phase, data on the independent variable, the moderator, and demographic variables were collected. In the second phase, data on the mediator variable were collected. In the third phase, data on the outcome variable were collected. The data collection rounds were separated by a time lag of two months. Our data collection teams' efforts and their recurring reminders to respondents brought fruitful results and we received 560, 531, and 476 responses in the first, second, and the third phase of data collection, respectively. After screening the data for missing data, 471 useable responses were received. The respondents for this study were managers and other members of the administration staff that were using the internet and other IT-based facilities for their routine tasks. These managers were directly involved in policymaking and decision-making. The respondents included general managers, director of finance, director of marketing, director of food and beverages, front office manager, executive housekeeper, HR manager, chief security officer, R\&D manager, quality manager, IT manager, purchase manager, training manager, chief engineer, etc.

Demographics included business age (number of years in business), business size (number of employees in business), respondent education, and respondent experience. Responses about business age showed that $45 \%$ of hotels were operational for 10 years, $34 \%$ for 15 years, and $21 \%$ for 5 years. Responses about business size showed that $53 \%$ of hotels had more than 350 employees, $28 \%$ of hotels had 251-349 employees, and 19\% of hotels had 151-249 employees. In terms of respondents' experience, $59 \%$ of the respondents had more than 10 years of experience and the rest of the respondents had less than 5 years of experience. Respondents education showed that $30 \%$ had a master's degree, $55 \%$ of respondents had 14 years of education $(55 \%)$, and $15 \%$ of respondents had 18 or more years of education. 


\subsection{Scales and Measurement}

The scales used to measure the variables of this study were reflective scales. The developed questionnaire was discussed with five academic researchers and three general managers of 5-star hotels, and as a result, a few minor changes were made in the questionnaire. These suggestions were incorporated and a pretest was performed. All scales gauged responses on a five-point Likert scale, ' 1 ' (strongly disagree) to ' 5 ' (strongly agree).

\subsubsection{Independent Variable (the Use of ICTs)}

ICT adoption was measured using a 17-item scale. The scale had three dimensions covering ICT infrastructure, ICT reliance, and ICT criticality. The ICT infrastructure asked questions about the internet, connection type being used, the development of the website, and the installation of an internal network in the building(s), etc. The ICT reliance asked questions about the degree of utilization of ICTs in hotels' operations. The ICT criticality asked questions about the vital role that ICTs play in improving hotel performance. The ICT scale was adapted from Steinfield et al. [8].

\subsubsection{E-Marketing}

E-marketing was assessed by using a six-item scale adapted from the works of Berthon et al. [45], Shaltoni and West [59], and Srinivasan et al. [60]. These items asked the question about the extent to which hotels have implemented e-marketing activities.

\subsubsection{Organizational Readiness}

The moderating variable as measured using a six-item scale adapted from the Claiborne [54].

\subsubsection{Strategic Business Performance}

SBP was adapted from the work of Kim, Ko, Kim, Koh [6] Murray, Kotabe, Wildt [17] Cavusgil and Zou [18], which measured six aspects of SBP consisting of 16 items-(1) the extent to which hotels achieved their strategic goals, (2) the extent to which hotels achieved its profitability goals, (3) the level at which hotels achieved the sales or revenue growth and share growth goals, (4) the extent to which hotels achieved marketing strategies, (5) the extent to which hotels achieved a comparative strategic position relative to the three largest competitors, and (6) the extent to which hotels achieved a comparative financial position relative to its three largest competitors. These items were measured on five-point Likert scales, varying from ' 1 ' (not achieved at all) to ' 5 ' (achieved completely)' and comparative performance was rated on ' 1 ' (much lower) to ' 5 ' (much higher).

\subsection{Confirmatory Factor Analysis}

We conducted confirmatory factor analysis (CFA) to check the distinctiveness of the variables of ICT, E-marketing, Organizational Readiness, and SBP. Results of our hypothesized four-factor model and three alternative models were developed to identify the best model [61]. The fit indices, $\chi^{2}=$ $157.46, \mathrm{CFI}=0.91, \mathrm{GFI}=0.93, \mathrm{RMSEA}=0.046$, showed the overall model fitness. The value of RMSEA was less than 0.05 and the values of GFI and CFI were greater than 0.90 , meeting the threshold levels. Model fitness was verified using the guidelines of Anderson and Gerbing [61].

Convergent, content, and discriminant validity were also assessed. The content validity of the constructs was assessed through in-depth literature review and formal meetings with professionals. Convergent validity was satisfactory, as loadings were above 0.70 and Average Variance Extracted (AVE) was above 0.50 [62]. Using the method suggested by Fornell and Larcker [62], the discriminant validity was examined. The Average Variance Extracted (AVE) of each of the latent constructs was greater than the shared variance of the constructs with every other construct. The values of composite reliability $(\mathrm{CR})$ were found to be higher than 0.60 , whereas the values of $\alpha$ (Cronbach alpha) were 
above 0.70 . Thus, the overall findings demonstrated that the measures used in the study were valid and reliable. The details of items' standard loadings, $t$-values, AVE, and CR are shown in Table 1.

Table 1. Results of CFA showing Standard Loading, $\mathrm{T}=$ Value, Average Variance Extracted (AVE), composite reliability (CR), and $\alpha$.

\begin{tabular}{|c|c|c|c|c|c|}
\hline Measures Details & SL & T-Value & AVE & CR & $\alpha$ \\
\hline $\begin{array}{l}\text { Information Communication and Technology } \\
\text { (ICT-17 items) }\end{array}$ & & & 0.72 & 0.96 & 0.88 \\
\hline ICT-1 & 0.71 & 12.87 & & & \\
\hline ICT-2 & 0.73 & 14.04 & & & \\
\hline ICT-3 & 0.75 & 17.18 & & & \\
\hline ICT-4 & 0.77 & 18.12 & & & \\
\hline ICT-5 & 0.79 & 14.03 & & & \\
\hline ICT-6 & 0.78 & 11.23 & & & \\
\hline ICT-7 & 0.83 & 14.05 & & & \\
\hline ICT-8 & 0.85 & 16.23 & & & \\
\hline ICT-9 & 0.81 & 12.32 & & & \\
\hline ICT-10 & 0.83 & 13.56 & & & \\
\hline ICT-11 & 0.82 & 15.32 & & & \\
\hline ICT-12 & 0.76 & 13.54 & & & \\
\hline ICT-13 & 0.78 & 16.85 & & & \\
\hline ICT-14 & 0.74 & 12.32 & & & \\
\hline ICT-15 & 0.81 & 12.13 & & & \\
\hline ICT-16 & 0.72 & 19.18 & & & \\
\hline ICT-17 & 0.77 & 15.32 & & & \\
\hline E-marketing adoption (6-items) & & & 0.74 & 0.94 & 0.94 \\
\hline EM-1 & 0.79 & 15.74 & & & \\
\hline EM-2 & 0.77 & 14.88 & & & \\
\hline EM-3 & 0.82 & 13.23 & & & \\
\hline EM-4 & 0.83 & 19.52 & & & \\
\hline EM-5 & 0.78 & 14.87 & & & \\
\hline EM-6 & 0.81 & 18.65 & & & \\
\hline Organizational Readiness & & & 0.78 & 0.94 & 0.89 \\
\hline OR-1 & 0.83 & 13.98 & & & \\
\hline OR-2 & 0.85 & 12.35 & & & \\
\hline OR-3 & 0.77 & 13.78 & & & \\
\hline OR-4 & 0.79 & 16.23 & & & \\
\hline OR-5 & 0.81 & 12.32 & & & \\
\hline OR-6 & 0.77 & 15.88 & & & \\
\hline Strategic Business Performance & & & 0.75 & 0.92 & 0.88 \\
\hline SBP-1 & 0.76 & 14.65 & & & \\
\hline SBP-2 & 0.82 & 15.45 & & & \\
\hline SBP-3 & 0.81 & 16.32 & & & \\
\hline SBP-4 & 0.77 & 12.99 & & & \\
\hline SBP-5 & 0.83 & 16.88 & & & \\
\hline SBP-6 & 0.78 & 17.55 & & & \\
\hline SBP-7 & 0.82 & 19.44 & & & \\
\hline SBP-8 & 0.84 & 17.21 & & & \\
\hline SBP-9 & 0.79 & 15.78 & & & \\
\hline SBP-10 & 0.76 & 14.14 & & & \\
\hline SBP-11 & 0.84 & 13.69 & & & \\
\hline SBP-12 & 0.81 & 14.67 & & & \\
\hline SBP-13 & 0.78 & 15.37 & & & \\
\hline SBP-14 & 0.79 & 13.95 & & & \\
\hline SBP-15 & 0.81 & 14.02 & & & \\
\hline SBP-16 & 0.82 & 16.54 & & & \\
\hline
\end{tabular}




\section{Analysis}

To test the study hypotheses $\mathrm{H} 1, \mathrm{H} 2$, and $\mathrm{H} 3$, regression analysis was used. To test the mediating effect of e-marketing in the ICT-SBP relationship, Preacher and Hayes' [63] approach was used. This approach allowed for the examination of the significance of the differences between total effect and direct effect. Table 2 depicts the results of means, standard deviation, and correlations. The VIF scores were below the cut-off values of 10.0 that proved that there was no issue of multi-collinearity.

Table 2. Mean, standard deviation, and correlation.

\begin{tabular}{ccccccccc}
\hline Variables & $\mathbf{1}$ & $\mathbf{2}$ & $\mathbf{3}$ & $\mathbf{4}$ & $\mathbf{5}$ & $\mathbf{6}$ & $\mathbf{7}$ & $\mathbf{8}$ \\
\hline 1. Business Age & 1 & & & & & & & \\
2. Number of Employees & 0.03 & 1 & & & & & & \\
3. Respondent Experience & $0.10^{*}$ & 0.06 & 1 & & & & & \\
4. Respondent Education & 0.04 & -0.20 & -0.03 & 1 & & & & \\
5. ICT & -0.06 & -0.13 & 0.04 & -0.04 & 1 & & & \\
6. E-marketing & 0.05 & -0.14 & -0.09 & $0.10^{*}$ & $0.31^{* *}$ & 1 & & \\
7. Organizational Readiness & 0.08 & -0.21 & -0.11 & -0.03 & $0.24^{* *}$ & $0.46^{* *}$ & 1 & \\
8. Strategic Business & -0.04 & 0.07 & -0.02 & -0.09 & $0.17^{* *}$ & $0.34^{* *}$ & $0.40^{* *}$ & 1 \\
$\quad$ Performance & 2.69 & 2.11 & 3.01 & 3.15 & 3.762 & 3.751 & 3.525 & 3.713 \\
$\quad$ Mean & 0.71 & 0.69 & 0.75 & 0.76 & 0.426 & 0.409 & 0.428 & 0.401 \\
\hline Standard Deviation &
\end{tabular}

Notes: Age and Number of employees were measured in three categories. Respondent experience was measured via four categories. Respondent education was measured by 6 categories. ${ }^{*} p<0.05$; ${ }^{* *} p<0.01$ (2-tailed).

Table 3 depicts the results of $\mathrm{H} 1, \mathrm{H} 2$, and $\mathrm{H} 3$. H1 proposed that ICT is positively associated with SBP. Table 3 shows that ICT predicted SBP and hypothesis 1 was accepted (Beta value $=0.289$, $p<0.001)$. Hypothesis 2 proposed that ICT predicts e-marketing. Results of $\mathrm{H} 2$ are presented in Table 3 and it was proved that ICT positively affected e-marketing $(\mathrm{B}=0.463, p<0.001)$. H3 proposed that e-marketing is positively associated with SBP. The results (shown in Table 3 ) proved that e-marketing had a significant positive association with SBP $(B=0.401, p<0.001)$.

Table 3. Regression results for the tests of $\mathrm{H} 1, \mathrm{H} 2$, and $\mathrm{H} 3$.

\begin{tabular}{cccccccc}
\hline Model & Details & $\mathbf{R}^{\mathbf{2}}$ & $\mathbf{F}$ & Beta & $\mathbf{T}$ & Sig & Remarks \\
\hline Model-1 & ICT SBP & 0.169 & 13.083 & 0.289 & 3.71 & 0.000 & H1 Accepted \\
Model-2 & ICT E-marketing & 0.316 & 52.018 & 0.463 & 7.21 & 0.000 & H2 Accepted \\
Model-3 & E-marketing SBP & 0.344 & 62.939 & 0.401 & 7.93 & 0.000 & H3 Accepted \\
\hline
\end{tabular}

\subsection{Results for Testing E-Marketing as a Mediator}

$\mathrm{H} 4$ proposed that the relationship between ICT and SBP is mediated by e-marketing. Based on Preacher and Hayes's approach [63], the bootstrap method was used to construct the confidence interval of ' $\mathrm{a} \times \mathrm{b}$ ' at the $95 \%$ level. Confidence interval did not overlap with zero for all hypotheses of the study, which confirmed that e-marketing mediated the relationship between ICT and SBP. The results are depicted in Table 3, where values of different paths $\left(a, b, c\right.$, and $\left.c^{\prime}\right)$ are shown. In Table 4, the results of bootstrapping are presented for evaluating the indirect effect of the independent variable on the dependent variable, via the mediating variable (ICT -> e-marketing $->\mathrm{SBP}$ ). According to Efron and Tibshirani [64], bootstrapping minimizes the errors of estimation. 
Table 4. Results of mediation effects showing paths a, b, c, and $c^{\prime}$.

\begin{tabular}{cccccc}
\hline Paths & Model Details & Coefficient & t-Value & SE & Sig \\
\hline $\begin{array}{c}\text { Path a (IV to Mediator) } \\
\text { Path b (Direct effect of Mediator }\end{array}$ & ICT E-marketing & 0.4627 & 7.2123 & 0.0642 & 0.000 \\
on DV) & E-marketing SBP & 0.3762 & 7.0706 & 0.0532 & 0.000 \\
Path c (Total effect of IV on DV) & ICT SBP & 0.2889 & 3.7188 & 0.0777 & 0.000 \\
Path c' (Direct effect of IV on DV) & ICT SBP & 0.1148 & 1.4739 & 0.0779 & 0.1412
\end{tabular}

\begin{tabular}{cccccccc}
\hline \multicolumn{7}{c}{ Bootstrap for the Indirect Effect of IV on DV through Mediator “ab path" } \\
\hline Model Detail & Data & Boot & Bias & SE & Lower & Upper & Sig \\
\hline ICT à E-marketing à SBP & 0.174 & 0.18 & 0.002 & 0.44 & 0.102 & 0.275 & 0 \\
\hline
\end{tabular}

Model summary for DV Model: R2 = 0.1224; F = 32.6341; $p=0.000$.

Table 4 shows the results of total and direct effects via different paths (a, b, c, and $\left.c^{\prime}\right)$ [52]. Results revealed that ICT was significantly and positively related to e-marketing $(\mathrm{B}=0.462, \mathrm{t}(469)=7.2123$, $p<0.001$, => 'a' path was significant). The mediating variable e-marketing was positively associated with SBP $(B=0.376, t(469)=7.077, \mathrm{p}<0.001,=>$ ' $\mathrm{b}$ ' path was significant). ICT was positively associated with SBP $(B=0.288, t(469)=3.718, p=0.001$, path ' $c$ ' was significant). The results also proved that when e-marketing was controlled the direct effect of ICT on SBP was non-significant, indicating a full mediation $(\mathrm{B}=0.114, \mathrm{t}(469)=1.473$, $\mathrm{ns}$, showing that ' $\mathrm{c}$ ' path was non-significant). As the initial two results proved that paths ' $a$ ' and ' $b$ ' were significant, the bootstrapping method was employed to test the mediation. In the bootstrapping method, a 95\% confidence level was used. The last section of Table 4 shows the results of the mediation. The results showed that e-marketing mediated the relationship between ICT and SBP (B $=0.174, C I=0.102$ to 0.275$)$. Thus, $\mathrm{H} 4$ was also accepted.

Figure 2 presents the mediating role of e-marketing in the relationship between ICT and SBP.

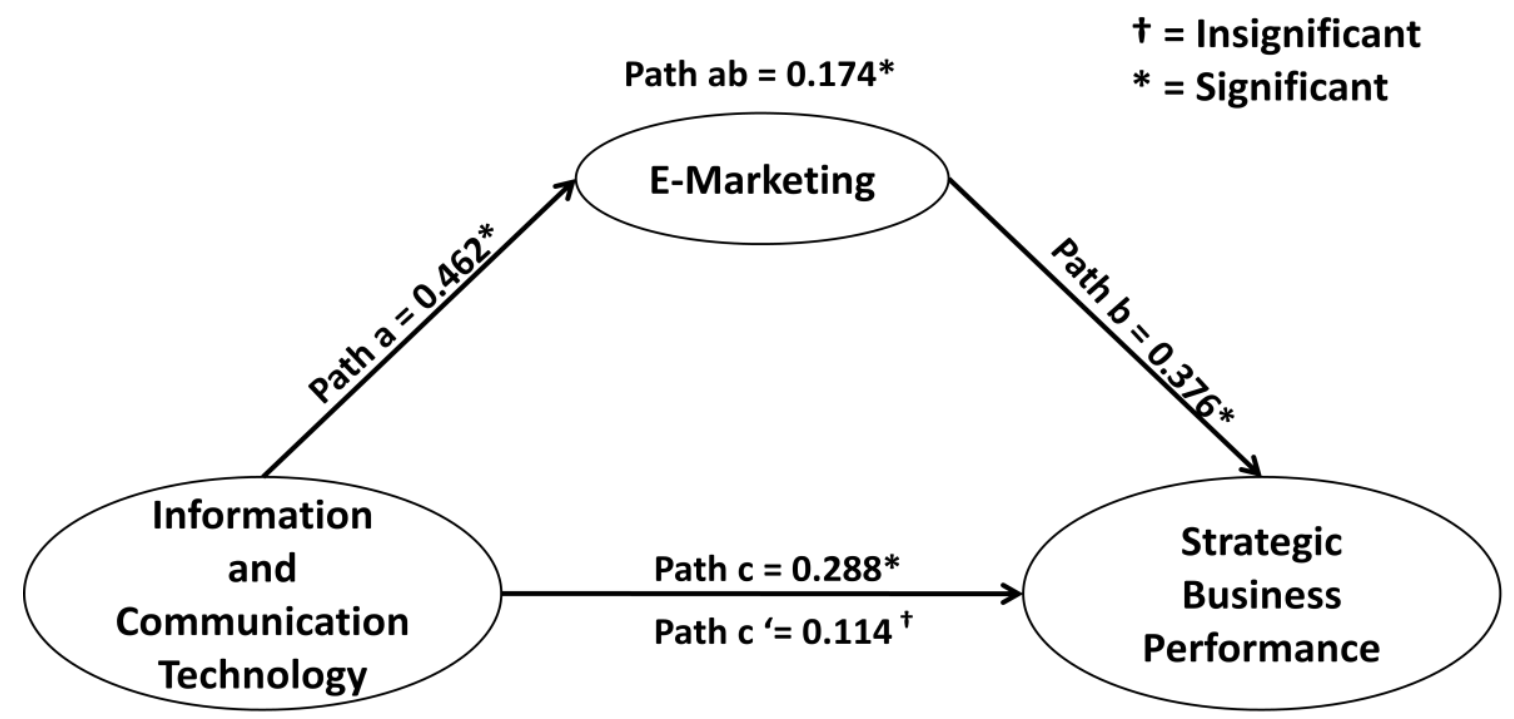

Figure 2. Mediation through e-marketing.

\subsection{Results for Testing Organizational Readiness as a Moderator}

We used hierarchical regression to analyze the moderating effect of organizational readiness. Results are presented in Table 5; Model 1 presents control variables and Model 2 shows the effect of ICT on e-marketing. Model 2 shows that ICT was positively related with e-marketing $(B=0.264, p<0.01$. Model 3 shows that organizational readiness was positively associated with e-marketing $(B=0.549$, $p<0.01$. Hypothesis 5 predicted the moderating impact of organizational readiness on the relationship of ICT with e-marketing. To test this hypothesis, an interaction term was added [65] in Model 4, which 
showed that the interaction effect between the connection of ICT and e-marketing was positive and significant $(B=0.160, p<0.01)$. The plots in Figure 3 indicates that the relationship between ICT and e-marketing was strong when organizational readiness was high, while the relationship was weak when organizational readiness was low, supporting $\mathrm{H} 5$.

Table 5. Regression results for testing Org Readiness as a moderator.

\begin{tabular}{ccccc}
\hline Details & Step 1 & Step 2 & \multicolumn{2}{c}{ Step 3 } \\
\cline { 4 - 5 } & Model 1 & Model 2 & Model 3 & Model 4 \\
\hline Business Age & -0.046 & -0.033 & -0.111 & -0.012 \\
No of Employees & -0.135 & -0.103 & 0.032 & $0.192^{*}$ \\
Respondent Experience & -0.014 & -0.02 & 0.020 & $0.340^{* *}$ \\
Respondent Education & -0.205 & -0.188 & -0.120 & \\
ICT & & $0.264^{* *}$ & 0.070 & $0.440^{* *}$ \\
Org Readiness & & & $0.549^{* *}$ & \\
ICT x Org Readiness & & & & $0.160^{* *}$ \\
Adjusted R & 0.012 & $0.148^{* *}$ & $0.260^{* *}$ & $0.290^{* *}$ \\
$\Delta \mathrm{R}^{2}$ & & $0.94^{* *}$ & $0.126^{* *}$ & $0.156^{* *}$ \\
$\Delta \mathrm{F}$ & & 51.326 & 113.346 & 124.33 \\
\hline
\end{tabular}

Notes: Level of significance: ${ }^{* *} p<0.01 ;{ }^{*} p<0.05$.

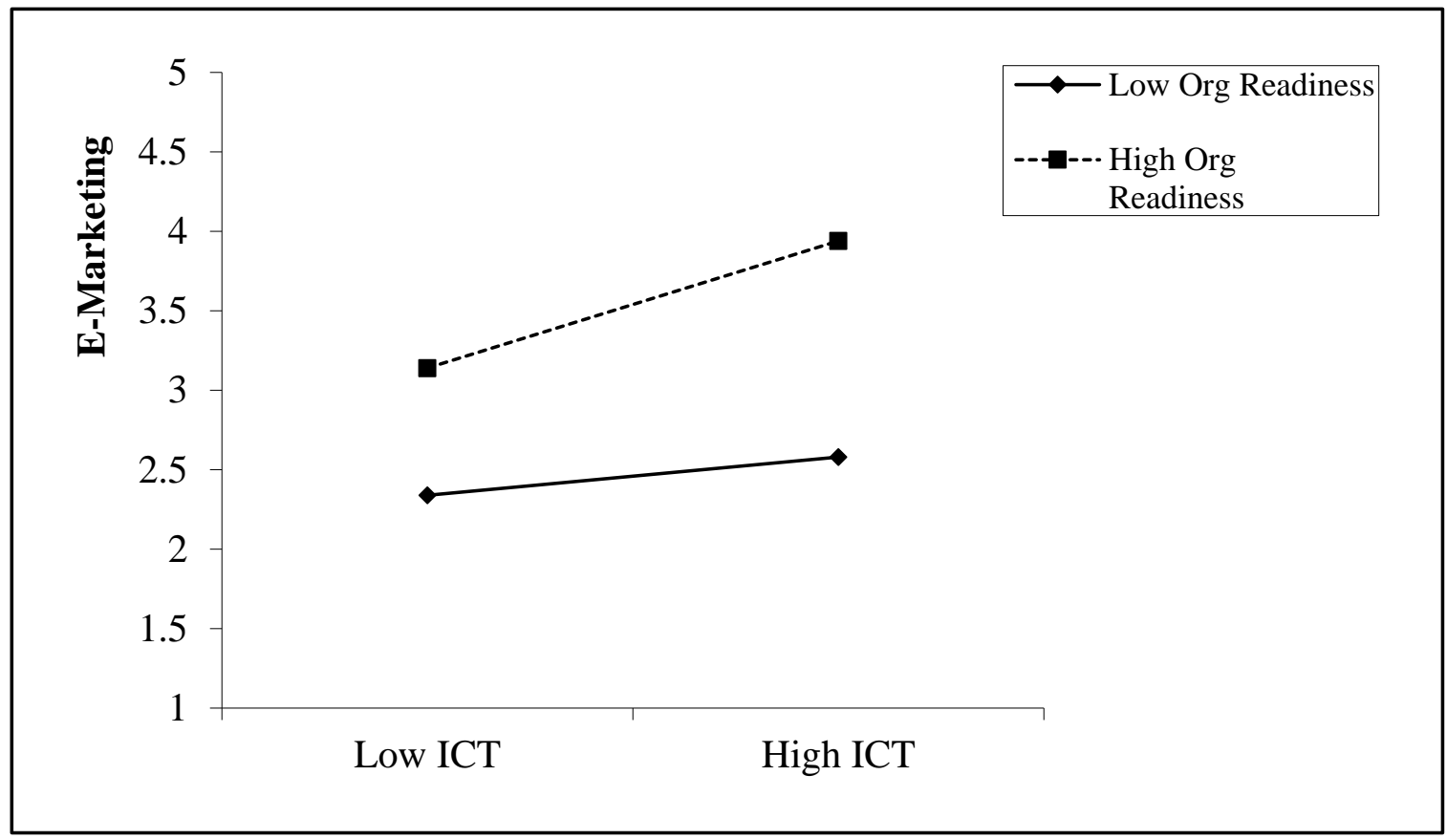

Figure 3. Moderating effect of organizational readiness in the information and communication technologies (ICT)- strategic business performance (SBP).

\section{Discussion and Conclusions}

Due to the advancement and impact of ICTs on businesses, a number of researchers have explored the effects of ICTs on business performance [15], financial development [38], and innovation and productivity $[49,51]$. However, the role of ICT in positively shaping SBP has been ignored. This is a surprising omission, given that SBP is a comprehensive scale that measures firms' achievements in terms of its financial targets, comparative performance, and the implementation of major business strategies. Moreover, the relationship between ICT and SBP has not been studied in the hospitality industry. Likewise, the relationship between ICT and e-marketing in developing countries, such as 
Pakistan, has largely been glossed over. To address these gaps, this study examined the direct and indirect (via e-marketing) effects of ICT on SBP in the hospitality industry. The study also examined the moderating role of organizational readiness in the relationship between ICT and e-marketing, in the hospitality context of Pakistan. In essence, this study offered a framework that provides several theoretical and practical implications related to the role of ICT and organizational readiness in positively shaping hospitality firms' e-marketing practices and SBP.

ICTs provide several opportunities for hotels to achieve long-term business objectives and stay competitive. SBP is influenced by various features of online marketing activities provided by ICT [35,43]. The results of H1 indicated that ICT adoption by hotels could enable them to perform strategically. Our study suggested a framework that provides guidance to hotels in developing countries, for achieving SBP through ICT. H2 of this study also confirmed that ICT has a positive influence on e-marketing. The results of the hypothesis supported the work of previous researchers who studied ICT and e-marketing [20]. Therefore, it is argued that the effective use of ICT could enable hotels to bring advancement in e-marketing activities. The results of $\mathrm{H} 3$ indicates that e-marketing positively influenced SBP. These results suggest that e-marketing can help firms to perform strategically and achieve SBP. Concerning the main focus of this study, numerous products of ICT (software, gadgets) were found to affect SBP through e-marketing. The results of H4 suggest that organizations that implement ICT are able to make effective use of online marketing [35], which, in turn, can lead firms to achieve SBP.

Researchers have suggested that organizational readiness is a key factor in the adoption of change [42,44]. In line with this finding, this research examined the moderating role of organizational readiness in the relationship between ICT and e-marketing. The inclusion of the moderating variable explained the instances when ICT can be more effective in positively contributing to e-marketing. The results showed that a higher level of organizational readiness can play a significant role in the effective use of e-marketing. Overall, this study contributes to different important streams of literature-ICT, e-marketing, SPB, and organizational readiness-by showing when and why ICT can help firms achieve SBP.

\subsection{Theoretical Implications}

The present work provides several theoretical implications for the growing body of research on ICTs, e-marketing, and SBP. Previous studies on ICT in the enterprise context have focused solely on performance based on conventional measures [6,44]. The present study extended the existing literature by focusing on strategic performance and explicated how ICTs and e-marketing can positively influence SBP. In doing so, the present study offered a more comprehensive framework of looking at firms' business performance.

Additionally, previous research studies have investigated different facets of ICTs, such as e-business, e-commerce [49], e-shopping [35], and e-marketing, in relationship with firms' performance based on traditional financial or operational measures of performance [32]. However, this study contributed to this stream of literature by highlighting the potential of e-marketing for helping firms achieve SBP by examining the mediating role of e-marketing, in the relationship between ICTs and SBP. Specifically, the current study presented the SBP model for firms operating in the hospitality industry by providing them guidance about how ICT leads to e-marketing, which, in turn, enables the hospitality sector firms to attain strategic performance. This research also studied and explained the moderating role of organizational readiness in the relationship between ICT and e-marketing. Organizational readiness can support management to utilize ICT for advancing e-marketing practices. This extension to the conceptual framework by considering the moderating role of organizational readiness is a major input to the existing theory.

Finally, we developed an SBP model that explains how hospitality firms can achieve SBP through ICTs and e-marketing by contextualizing the theoretical links between ICTs, e-marketing, and SPB, in a developing country. This is an important contribution, given the growing recognition of Pakistan 
as a tourism destination, the importance of the hospitality sector for the tourism industry, and the imperative role that the tourism sector plays in the economic development of different countries.

\subsection{Practical Implications}

The current work provides some important practical implications for the hospitality industry. First, the study offers hotel managers/owners a better understanding of the interrelationships between ICT, e-marketing, and SBP, which can help them achieve SBP. It is strongly recommended to hotel management that they adopt the latest developments in ICTs and integrate them into their firms' marketing strategies. Second, frequent and customized interactions with existing and potential customers through mobile phones and over the internet can enable hotel management to stimulate customer response instantly, understand their needs, and offer them customized solutions. The management can directly communicate with its customers regarding discount offerings and price-cut packages that can enhance customers' intention and loyalty. Third, consistent improvement and updated information on websites enhance the effect of marketing activities on customers' buying behavior, which can result in increased revenues and market share. Such e-marketing can enable hotel management to develop long-term relationships with the customers and achieve SBP.

Fourth, one of the key advantages of using ICT is that it provides online reservations, which can create convenience for customers and encourage them in the repeated use of the hotel's services. Finally, ICTs can play a prominent role in helping hotels to achieve SBP by providing information-sharing platforms and by sharing customer reviews, which can attract more customers. Such platforms can inspire customers to avail of online services, which would increase a firm's financial performance by reducing costs and increasing the profit margin. In conclusion, this study overcomes the limitations of previous research in the hospitality sector while providing information about how hotels can enhance SBP through ICTs and e-marketing.

\subsection{Limitations and Future Research}

Besides all significant contributions, this research also endures certain limitations. First, this study targets the achievement of SBP through ICT and e-marketing in the context of the hospitality sector only. Further researches should investigate the possible effects of ICT and e-marketing on clusters of other sectors. Another point that ought to be considered when interpreting findings is that our model has evaluated e-marketing as a mediating variable in the ICT-SBP relationship. However, the current study model can be made more comprehensive by adding other factors like innovation, inter, and intra-organization relationships as moderating/mediating variables between the ICT and SBP. Therefore, future research could be conducted to examine the impact of these variables on a hotel's SBP. Finally, it is acknowledged that this study was based on a time-lagged design, which helps reduce common method variance but limits drawing strong causal inferences. We suggest experimental and longitudinal designs in future studies.

Author Contributions: Conceptualization, M.K.A., M.U. and Z.Y.; methodology, S.Y., M.U. and Z.Y.; software, M.U. and Z.Y.; validation, M.K.A., Z.Y., S.Y. and M.U.; formal analysis, M.K.A. and S.Y.; investigation, M.U. and Z.Y.; resources, M.K.A. and Z.Y.; data curation, M.U. and Z.Y.; writing-original draft preparation, M.K.A., S.Y., Z.Y. and M.U.; writing—review and editing, M.U., S.Y., and Z.Y.; visualization, M.K.A., S.Y., Z.Y. and M.U.; supervision, Z.Y. and M.U.; project administration, M.A.K., M.U., S.Y., and Z.Y. All authors have read and agreed to the published version of the manuscript.

Funding: Xi'an University of Architecture and Technology, China, Address: 13 yanta zhong lu, xi'an, China.

Conflicts of Interest: The authors declare no conflict of interest.

\section{References}

1. Stankov, U.; Filimonau, V.; Slivar, I. Calm ICT design in hotels: A critical review of applications and implications. Int. J. Hosp. Manag. 2019, 82, 298-307. [CrossRef] 
2. Zikria, Y.B.; Kim, S.W.; Hahm, O.; Afzal, M.K.; Aalsalem, M.Y. Internet of Things (IoT) operating systems management: Opportunities, challenges, and solution. Sensors 2019, 19, 1793. [CrossRef] [PubMed]

3. Barwise, P.; Farley, J.U. The State of Interactive Marketing in Seven Countries: Interactive Marketing Comes of Age. J. Int. Mark. 2005, 19, 67-80. [CrossRef]

4. Bayo-Moriones, A.; Billón, M.; Lera-López, F. Perceived performance effects of ICT in manufacturing SMEs. Ind. Manag. Data Syst. 2013, 113, 117-135. [CrossRef]

5. Law, R.; Leung, D.; Chan, I.C.C. Progression and development of information and communication technology research in hospitality and tourism. Int. J. Contemp. Hosp. Manag. 2019. [CrossRef]

6. Kim, E.Y.; Ko, E.; Kim, H.; Koh, C.E. Comparison of benefits of radio frequency identification: Implications for business strategic performance in the US and Korean retailers. Ind. Mark.Manag. 2008, 37, 797-806. [CrossRef]

7. Higon, D.A. The impact of ICT on innovation activities: Evidence for UK SMEs. Int. Small Bus. J. 2011, 30, 684-699. [CrossRef]

8. Steinfield, C.; LaRose, R.; Chew, H.E.; Tong, S.T. Small and medium-sized enterprises in rural business clusters: The relation between ICT adoption and benefits derived from cluster membership. Inform. Soc. 2012, 28, 110-120. [CrossRef]

9. Saleem, F.; Salim, N.; Altalhi, A.H.; Ullah, Z.; AL-Malaise AL-Ghamdi, A.; Mahmood Khan, Z. Assessing the effects of information and communication technologies on organizational development: Business values perspectives. Inform. Technol. Dev. 2020, 26, 54-88. [CrossRef]

10. Jorgenson, D.W.; Vu, K.M. The ICT revolution, world economic growth, and policy issues. Telecommun. Policy 2016, 40, 383-397. [CrossRef]

11. Pérez-López, R.J.; OlguínTiznado, J.E.; MojarroMagaña, M.; Camargo Wilson, C.; López Barreras, J.A.; García-Alcaraz, J.L. Information sharing with ICT in production systems and operational performance. Sustainability 2019, 11, 3640. [CrossRef]

12. Ollo-Lopez, A.; Aramendia-Muneta, M.E. ICT impact on competitiveness, innovation and environment. Telematics Inform. 2012, 29, 204-210. [CrossRef]

13. Díaz, E.; Martín-Consuegra, D.; Esteban, Á. Is ICT good for employees?An analysis of its effects on sales agents' perceptions of service cannibalization. Comput. Hum. Behav. 2015, 51, 263-271. [CrossRef]

14. El Kadiri, S.; Grabot, B.; Thoben, K.D.; Hribernik, K.; Emmanouilidis, C.; Von Cieminski, G.; Kiritsis, D. Current trends on ICT technologies for enterprise information systems. Comput. Ind. 2016, 79, 14-33. [CrossRef]

15. Salavati, S.; Hashim, N.H. Website adoption and performance by Iranian hotels. Tourism Manag. 2015, 46, 367-374. [CrossRef]

16. Yeo, B.; Grant, D. Exploring the factors affecting global manufacturing performance. Inform. Technol. Dev. 2019, 25, 92-121. [CrossRef]

17. Murray, J.Y.; Kotabe, M.; Wildt, A.R. Strategic and financial performance implications of global sourcing strategy: A contingency analysis. J. Int. Bus. Stud. 1995, 26, 181-202. [CrossRef]

18. Cavusgil, S.T.; Zou, S. Marketing strategy-performance relationship: An investigation of the empirical link in export market ventures. J. Mark. 1994, 58, 1-21. [CrossRef]

19. Usman, M.; Ahmad, M.I.; Burgoyne, J. Individual and organizational learning from inter-firm knowledge sharing: A framework integrating inter-firm and intra-firm knowledge sharing and learning. Can. J. Adm. Sci./Rev. Can. Sci. de l'Adm. 2019, 36, 484-497. [CrossRef]

20. Weeks, W.A.; Roberts, J.; Chonko, L.B.; Jones, E. Organizational readiness for change, individual fear of change, and sales manager performance: An empirical investigation. J. Personal Selling Sales Manag 2004, 24, 7-17. [CrossRef]

21. Liu, M.T.; Wong, I.A.; Tseng, T.H.; Chang, A.W.Y.; Phau, I. Applying consumer-based brand equity in luxury hotel branding. J. Bus. Res. 2017, 81, 192-202. [CrossRef]

22. Lozada, G.A. The Hotelling Rule for Entropy-constrained Economic Growth. Ecol. Econ. 2017, 133, 35-41. [CrossRef]

23. Hitt, L.M.; Brynjolfsson, E. Productivity, business profitability, and consumer surplus: Three different measures of information technology value. MIS Q. 1996, 20, 121-142. [CrossRef]

24. Berné, C.; García-González, M.; García-Uceda, M.E.; Múgica, J.M. The effect of ICT on relationship enhancement and performance in tourism channels. Tourism Manag. 2015, 48, 188-198. [CrossRef] 
25. Devaraj, S.; Kohli, R. Performance impacts of information technology: Is actual usage the missing link? Manag. Sci. 2003, 49, 273-289. [CrossRef]

26. Lin, C.H.; Shih, H.Y.; Sher, P.J. Integrating technology readiness into technology acceptance: The TRAM model. Psychol. Market. 2007, 24, 641-657. [CrossRef]

27. Lobo, S.R.; Samaranayake, P.; Subramanian, N. The impact of TQM and information communication technology (ICT) as an enabler in the quality management assessment framework (QMAF) on business outcomes. Int. J. Syst. Sci. Op. Logistics 2019, 6, 69-85. [CrossRef]

28. Chege, S.M.; Wang, D.; Suntu, S.L. Impact of information technology innovation on firm performance in Kenya. Inf. Technol. Dev. 2019, 1-30. [CrossRef]

29. Chege, S.M.; Wang, D. The influence of technology innovation on SME performance through environmental sustainability practices in Kenya. Technol. Soc. 2020, 60, 101210. [CrossRef]

30. Brady, M.; Fellenz, M.R.; Brookes, R. Researching the role of information and communications technology (ICT) in contemporary marketing practices. J. Bus. Ind. Mark. 2008, 23, 108-114. [CrossRef]

31. Rasel, F. ICT and global sourcing-evidence for German manufacturing and service firms. Econ. Innov. New Technol. 2017, 26, 634-660. [CrossRef]

32. Idota, H.; Bunno, T.; Tsuji, M. Impact of ICT on innovation: The case of Japanese SMEs. In Disruptive Technology: Concepts, Methodologies, Tools, and Applications; IGI Global: Hershey, PA, USA, 2020; pp. 1624-1651.

33. Gërguri-Rashiti, S.; Ramadani, V.; Abazi-Alili, H.; Dana, L.P.; Ratten, V. ICT, innovation and firm performance: The transition economies context. Thunderbird Int. Bus. Rev. 2017, 59, 93-102. [CrossRef]

34. Halkos, G.E.; Tzeremes, N.G. International competitiveness in the ICT industry: Evaluating the performance of the top 50 companies. Glob. Econ. Rev. 2007, 36, 167-182. [CrossRef]

35. Hoffman, D.L.; Novak, T.P. Marketing in hypermedia computer-mediated environments: Conceptual foundations. J. Mark. 1996, 60, 50-68. [CrossRef]

36. Ching, H.L.; Ellis, P. Marketing in cyberspace: What factors drive e-commerce adoption? J. Mark. Manag. 2004, 20, 409-429. [CrossRef]

37. Racela, O.C.; Thoumrungroje, A. Enhancing export performance through proactive export market development capabilities and ICT utilization. J. Glob. Mark. 2019, 1-18. [CrossRef]

38. Brodie, R.J.; Winklhofer, H.; Coviello, N.E.; Johnston, W.J. Is e-marketing coming of age? An examination of the penetration of e-marketing and firm performance. J. Int. Mark. 2007, 21, 2-21. [CrossRef]

39. Yan, R. Cooperative advertising, pricing strategy and firm performance in the e-marketing age. J. Acad. Mark. Sci. 2010, 38, 510-519. [CrossRef]

40. Eid, R.; El-Gohary, H. The impact of E-marketing use on small business enterprises' marketing success. Serv. Ind. J. 2013, 33, 31-50. [CrossRef]

41. Constantinides, E. The marketing mix revisited: Towards the 21st century marketing. J. Mark. Manag. 2006, 22, 407-438. [CrossRef]

42. Gilmore, A.; Gallagher, D.; Henry, S. E-marketing and SMEs: Operational lessons for the future. Eur. Bus. Rev. 2007, 19, 234-247. [CrossRef]

43. Li, M.; Ye, L.R. Information technology and firm performance: Linking with environmental, strategic and managerial contexts. Inf. Manag. 1999, 35, 43-51. [CrossRef]

44. Lindsey-Mullikin, J.; Borin, N. Why strategy is key for successful social media sales. Bus. Horizons 2017, 60, 473-482. [CrossRef]

45. Berthon, P.; Ewing, M.; Pitt, L.; Naudé, P. Understanding B2B and the Web: The acceleration of coordination and motivation. Ind. Mark. Manag. 2003, 32, 553-561. [CrossRef]

46. Biagi, F.; Falk, M. The impact of ICT and e-commerce on employment in Europe. J. Policy Model. 2017, 39, 1-18. [CrossRef]

47. Cambra-Fierro, J.; Melero, I.; Sese, F.J. Online customer-initiated contacts and the development of profitable relationships. Electron. Commerce Res. Appl. 2017, 26, 13-22. [CrossRef]

48. Hew, J.J.; Lee, V.H.; Ooi, K.B.; Lin, B. Mobile social commerce: The booster for brand loyalty? Comput. Hum. Behav. 2016, 59, 142-154. [CrossRef]

49. Johnston, D.A.; Wade, M.; McClean, R. Does e-business matter to SMEs? A comparison of the financial impacts of internet business solutions on European and North American SMEs. J. Small Bus. Manag. 2007, 45, 354-361. [CrossRef] 
50. Kim, E.; Nam, D.I.; Stimpert, J.L. Testing the applicability of Porter's generic strategies in the digital age: A study of Korean cyber malls. J. Bus. Strateg. 2004, 21, 19.

51. Wang, L.; Law, R.; Guillet, B.D.; Hung, K.; Fong, D.K.C. Impact of hotel website quality on online booking intentions: E Trust as a mediator. Int. J. Hosp. Manag. 2015, 47, 108-115. [CrossRef]

52. Wang, Y.S.; Li, H.T.; Li, C.R.; Zhang, D.Z. Factors affecting hotels' adoption of mobile reservation systems: A technology-organization-environment framework. Tourism Manag. 2016, 53, 163-172. [CrossRef]

53. Chan-Olmsted, S. Branding and Internet marketing in the age of digital media. J. Broadcast. Electron. Media 2002, 46, 641-645. [CrossRef]

54. Claiborne, N.; Auerbach, C.; Lawrence, C.; Schudrich, W.Z. Organizational change: The role of climate and job satisfaction in child welfare workers' perception of readiness for change. Children Youth Serv. Rev. 2013, 35. [CrossRef]

55. Giotopoulos, I.; Kontolaimou, A.; Korra, E.; Tsakanikas, A. What drives ICT adoption by SMEs? Evidence from a large-scale survey in Greece. J. Bus. Res. 2017, 81, 60-69. [CrossRef]

56. Dyerson, R.; Spinelli, R.; Harindranath, G. Revisiting IT readiness: An approach for small firms. Ind. Manag. Data Syst. 2016, 116, 546-563. [CrossRef]

57. Backer, T.E. Assessing and enhancing readiness for change: Implications for technology transfer. NIDA Res. Monogr. 1995, 155, 21-41.

58. Chiang, C.F. Perceived organizational change in the hotel industry: An implication of change schema. Int. J. Hosp. Manag. 2010, 29, 157-167. [CrossRef]

59. Shaltoni, A.M.; West, D.C. The measurement of e-marketing orientation (EMO) in business-to-business markets. Ind. Mark. Manag. 2010, 39, 1097-1102. [CrossRef]

60. Srinivasan, R.; Lilien, G.L.; Rangaswamy, A. Technological opportunism and radical technology adoption: An application to e-business. J. Mark. 2002, 66, 47-60. [CrossRef]

61. Anderson, J.C.; Gerbing, D.W. Structural equation modeling in practice: A review and recommended two-step approach. Psychol. Bull. 1988, 103, 411-423. [CrossRef]

62. Fornell, C.; Larcker, D.F. Evaluating structural equation models with unobservable variables and measurement error. J. Mark. Res. 1981, 18, 39-50. [CrossRef]

63. Preacher, K.J.; Hayes, A.F. Asymptotic and resampling strategies for assessing and comparing indirect effects in multiple mediator models. Behav. Res. Methods 2008, 40, 879-891. [CrossRef]

64. Efron, B.; Tibshirani, R.J. An Introduction to the Bootstrap; CRC Press LLC: Boca Raton, FL, USA, 1994.

65. Aiken, L.S.; West, S.G.; Reno, R.R. Multiple Regression: Testing and Interpreting Interactions; Sage: Thousand Oaks, CA, USA, 1991.

(C) 2020 by the authors. Licensee MDPI, Basel, Switzerland. This article is an open access article distributed under the terms and conditions of the Creative Commons Attribution (CC BY) license (http://creativecommons.org/licenses/by/4.0/). 